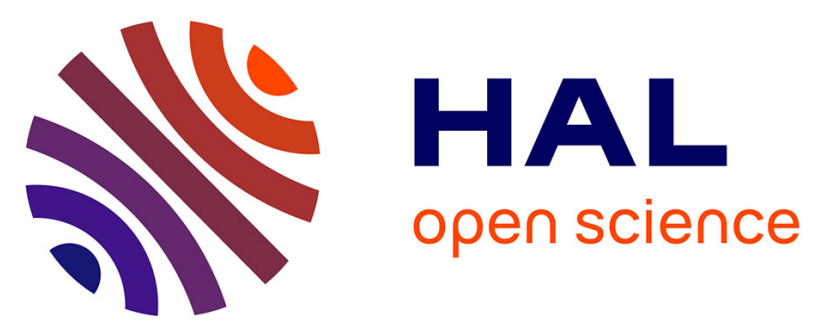

\title{
Reactivity differences between 2,4- and 2,5-disubstituted zirconacyclopentadienes: a highly selective and general approach to 2,4-disubstituted phospholes.
}

Guillaume Bousrez, Florian Jaroschik, Agathe Martinez, Dominique Harakat, Emmanuel Nicolas, X. F Le Goff, Jan Szymoniak

\section{To cite this version:}

Guillaume Bousrez, Florian Jaroschik, Agathe Martinez, Dominique Harakat, Emmanuel Nicolas, et al.. Reactivity differences between 2,4- and 2,5-disubstituted zirconacyclopentadienes: a highly selective and general approach to 2,4-disubstituted phospholes.. Dalton Transactions, 2013, epub ahead of print. $10.1039 / \mathrm{c} 3 \mathrm{dt} 51158 \mathrm{~h}$. hal-00839784

\section{HAL Id: hal-00839784}

https://hal-polytechnique.archives-ouvertes.fr/hal-00839784

Submitted on 1 Jul 2013

HAL is a multi-disciplinary open access archive for the deposit and dissemination of scientific research documents, whether they are published or not. The documents may come from teaching and research institutions in France or abroad, or from public or private research centers.
L'archive ouverte pluridisciplinaire HAL, est destinée au dépôt et à la diffusion de documents scientifiques de niveau recherche, publiés ou non, émanant des établissements d'enseignement et de recherche français ou étrangers, des laboratoires publics ou privés. 


\title{
Reactivity differences between 2,4- and 2,5-disubstituted zirconacyclopentadienes: a highly selective and general approach to 2,4- disubstituted phospholes.
}

\author{
Guillaume Bousrez, ${ }^{a}$ Florian Jaroschik, ${ }^{\text {a }}$ Agathe Martinez, ${ }^{a}$ Dominique Harakat, ${ }^{\text {a }}$ Emmanuel Nicolas, \\ ${ }_{5}$ Xavier F. Le Goff, ${ }^{\text {, Jan Szymoniak*a }}$
}

\author{
Received (in $X X X, X X X)$ Xth $X X X X X X X X X 20 X X$, Accepted Xth $X X X X X X X X X 20 X X$
}

DOI: $10.1039 / b 000000 x$

\begin{abstract}
Mixtures of 2,4- and 2,5-disubstituted zirconacyclopentadienes were obtained by the reductive coupling of terminal alkynes using the $\mathrm{Cp}_{2} \mathrm{ZrCl}_{2} /$ lanthanum system. Reactions of dihalophosphines with these

10 mixtures afforded selectively the corresponding 2,4-disubstituted phospholes and 1,4-disubstituted butadienes. The new series of phospholes was characterized by multi-nuclear NMR spectroscopy and Xray analysis. A possible explanation for the observed selectivity was obtained from X-ray studies and DFT analysis of the intermediate zirconacyclopentadienes.
\end{abstract}

\section{Introduction}

15 Zirconacyclopentadienes are important intermediates in organic synthesis, including transition-metal catalysis and macrocyclisation reactions. Since the first synthesis of tetraphenylzirconacyclopentadiene in 1961, several synthetic pathways have been explored. Especially, the emergence of low-

20 valent zirconocene precursors, such as the Negishi, Takahashi or Rosenthal reagents, has contributed considerably to their development. These complexes reductively couple internal alkynes with a large variety of substituents. The regioselectivity can be influenced by trimethylsilyl (alpha-position), 25 pentafluorophenyl or mesityl groups (beta-position). The hydrozirconation/methylation pathway developed by Buchwald is an interesting alternative as it gives readily access to trisubstituted complexes whereas the former reagents are especially suitable for tetrasubstituted compounds. However,

30 most reagents cannot be employed in the coupling of two terminal alkynes and disubstituted zirconacyclopentadienes have been rarely described. In most cases, mixtures of products were obtained which could not be further exploited. Only the very bulky tris(trimethylsilyl)silyl group afforded the 2,5-disubstituted 35 zirconacyclopentadiene as sole product. A switch to the bis(indenyl)zirconocene allows the 2,5-selective coupling of terminal alkynes. In 2006, the reductive dimerisation of terminal alkynes using a Mischmetall generated zirconocene(II) equivalent was described. These reactions yielded clean mixtures of 2,4- and 40 2,5-disubstituted zirconacyclopentadienes as shown by hydrolysis experiments. To date no further reaction involving 2,4disubstituted zirconacyclopentadienes has been reported.

Among the numerous transformations of zirconacyclopentadienes, the synthesis of 5-membered 45 heterocycles has attracted much interest. The so-called Fagan-
Nugent route involves the reaction of electrophilic main group halides based on boron, phosphorus, tin and others with zirconacyclopentadienes. We focused our interest on the synthesis of new phospholes, as they have recently become 50 important building blocks in the fields of catalysis, coordination chemistry, material sciences and medicinal chemistry. ${ }^{1-5}$ In addition, phospholide anions are interesting alternatives to cyclopentadienide ligands in organometallic chemistry. ${ }^{6}$ In view of these numerous applications, it seemed surprising that not all ${ }_{55}$ substitution patterns of phospholes have been investigated: the majority of phospholes is tetrasubstituted, with 2,5- and 3,4disubstituted phospholes being also readily accessible. ${ }^{7}$ In contrast, very few examples of 2,4-disubstituted phospholes are known and no general synthetic route to such compounds has 60 been reported. ${ }^{8}$ Such compounds may offer different steric and electronic properties, which could be exploited in ligand design for catalytic and organometallic purposes.

We report here a highly selective and general synthesis of 2,4disubstituted phospholes using the Fagan-Nugent route in 65 combination with the reductive coupling of terminal alkynes by the lanthanum generated zirconocene(II). An X-ray study and DFT calculations on the intermediate zirconacyclopentadienes offer some insights with respect to the observed selectivity.

\section{Experimental part}

70 All reactions were conducted under an argon atmosphere using standard Schlenk techniques and an argon-filled Jacomex BS531type dry box. Tetrahydrofuran and diethylether were collected under argon from a PURSOLV MD-3 (Innovative Technologie Inc.) solvent purification unit. Zirconocene dichloride was 75 purchased from Strem Chemicals. Alkynes were purchased from Aldrich and Alfa Aesar or synthetized from the corresponding aldehydes according to reported literature procedures. ${ }^{1}$ 
Lanthanum ingot was purchased from Aldrich and Strem Chemicals and freshly filed in the drybox prior to use. ${ }^{1} \mathrm{H},{ }^{13} \mathrm{C}$, ${ }^{19} \mathrm{~F},{ }^{29} \mathrm{Si}$ and ${ }^{31} \mathrm{P}$ NMR spectra were recorded in $\mathrm{CDCl}_{3}$, unless specified, on a $250 \mathrm{MHz}$ Bruker Avance I spectrometer equipped 5 with a QNP probe and a $500 \mathrm{MHz}$ Bruker Avance III spectrometer equipped with a BBFO+ probe. Chemical shifts are reported in delta $(\delta)$ units, expressed in parts per million (ppm). One and two dimensional experiments, including NOESY and HOESY $\left({ }^{1} \mathrm{H}-\right.$ ${ }^{31} \mathrm{P}$ ) experiments were performed for the NMR assignments of 10 phospholes. High resolution ESI-MS spectra were recorded on a hybrid tandem quadrupole/time-of-flight (Q-TOF) instrument, equipped with a pneumatically assisted electrospray (Z-spray) ion source (Micromass, Manchester, UK) operated in positive mode. High resolution EI-MS spectra were obtained on a GCT-TOF 15 mass spectrometer (Micromass, Manchester, UK) with EI source.

Synthesis of 1,4-diiodo-1,3- and 1,4-diphenylbutadienes 2a and $2 \mathbf{b}$. A Schlenk tube was loaded with zirconocene dichloride $\left(\mathrm{Cp}_{2} \mathrm{ZrCl}_{2}\right)(292 \mathrm{mg}, 1.0 \mathrm{mmol})$, lanthanum (93 mg, $\left.0.66 \mathrm{mmol}\right)$ and THF $(5 \mathrm{~mL})$. The resulting mixture was stirred vigorously at 20 room temperature until a deep red color appeared. At this stage, phenylacetylene $(0.21 \mathrm{ml}, 2 \mathrm{mmol})$ was added to the reaction mixture. After $3 \mathrm{~h}$, iodine $(570 \mathrm{mg}, 2.25 \mathrm{mmol})$ was added portion-wise at room temperature and the reaction was stirred for $24 \mathrm{~h}$. The resulting brown solution with a yellow precipitate was 25 quenched with aqueous $\mathrm{Na}_{2} \mathrm{~S}_{2} \mathrm{O}_{3}$ solution $(1 \mathrm{M}, 5 \mathrm{~mL})$ and water $(25 \mathrm{~mL})$ at room temperature. The aqueous layer was extracted with $\mathrm{Et}_{2} \mathrm{O}(3 \times 25 \mathrm{~mL})$, and the organic phases were combined, washed with brine, dried over $\mathrm{MgSO}_{4}$, and concentrated under vacuum. The red residue was purified by flash column 30 chromatography on silica gel using petroleum ether as eluent, yielding $\mathbf{2 a}$ and $\mathbf{2 b}$ in $25 \%$ (113 $\mathrm{mg}, 0.25 \mathrm{mmol})$ and $18 \%$ (82 $\mathrm{mg}, 0.18 \mathrm{mmol}$ ), respectively. NMR data of $\mathbf{2 a}$ and $\mathbf{2 b}$ are in accordance with the literature data. ${ }^{5}$

Optimised procedure for 1,2,4-triphenylphosphole. A Schlenk 35 tube was loaded with $\mathrm{Cp}_{2} \mathrm{ZrCl}_{2}(584 \mathrm{mg}, 2.0 \mathrm{mmol})$, lanthanum (186 mg, $1.3 \mathrm{mmol})$ and THF $(10 \mathrm{~mL})$. The resulting mixture was stirred vigorously at room temperature until a deep red color appeared. At this stage, the phenylacetylene $(0.42 \mathrm{~mL}, 4.0 \mathrm{mmol})$ was added to the reaction mixture and the stirring was continued 40 until complete disappearance of the alkyne as shown by TLC. Then the optimized amount of dichlorophenylphosphine $(0.14$ $\mathrm{mL}, 1.0 \mathrm{mmol}$ ) was added at $-78^{\circ} \mathrm{C}$. After slow warming to room temperature, the reaction mixture was stirred for $18 \mathrm{~h}$. After that time, petroleum ether $(20 \mathrm{~mL})$ was added to the brown solution 45 and the solution was filtered over a short column of basic aluminum oxide using petroleum ether/ethyl acetate 8:2 as eluent. The solvent was evaporated and the crude residue was purified by flash column chromatography on silica gel using petroleum ether to yield phosphole $3 \mathbf{a}$ in $70 \%$ yield (218 mg, $70 \mathrm{mmol}$ ). Crystals 50 suitable for X-ray analysis were obtained obtained by recrystallisation from diethyl ether. ${ }^{1} \mathrm{H} \mathrm{NMR}\left(500 \mathrm{MHz}, \mathrm{CDCl}_{3}\right.$ ): $7.08\left(\mathrm{dd}, \mathrm{J}_{\mathrm{P}-\mathrm{H}}=40.0 \mathrm{~Hz}, \mathrm{~J}_{\mathrm{H}-\mathrm{H}}=1.5 \mathrm{~Hz}, 1 \mathrm{H}, \mathrm{H} 1\right), 7.22-7.29(\mathrm{~m}$, $3 \mathrm{H}, \mathrm{H} 12, \mathrm{H} 15), 7.31\left(\mathrm{~d}, \mathrm{~J}_{\mathrm{H}-\mathrm{H}}=8.0 \mathrm{~Hz}, 2 \mathrm{H}, \mathrm{H} 11\right), 7.34-7.38(\mathrm{~m}$, $3 \mathrm{H}, \mathrm{H} 8, \mathrm{H} 16), 7.43$ (d, $\left.\mathrm{J}_{\mathrm{H}-\mathrm{H}}=7.0 \mathrm{~Hz}, 2 \mathrm{H}, \mathrm{H} 7\right), 7.46\left(\mathrm{~d}, \mathrm{~J}_{\mathrm{P}-\mathrm{H}}=7.5\right.$ $\left.{ }_{55} \mathrm{~Hz}, 2 \mathrm{H}, \mathrm{H} 14\right), 7.61\left(\mathrm{~d}, \mathrm{~J}_{\mathrm{H}-\mathrm{H}}=8.0 \mathrm{~Hz}, 2 \mathrm{H}, \mathrm{H} 10\right), 7.66\left(\mathrm{dd}, \mathrm{J}_{\mathrm{P}-\mathrm{H}}=\right.$ $\left.12.5 \mathrm{~Hz}, \mathrm{~J}_{\mathrm{H}-\mathrm{H}}=1.5 \mathrm{~Hz}, 1 \mathrm{H}, \mathrm{H} 3\right), 7.73\left(\mathrm{~d}, \mathrm{~J}_{\mathrm{H}-\mathrm{H}}=7.0 \mathrm{~Hz}, 2 \mathrm{H}, \mathrm{H} 6\right)$. ${ }^{13} \mathrm{C}$ NMR (125 MHz, $\left.\mathrm{CDCl}_{3}\right): 126.6\left(\mathrm{~d}, \mathrm{~J}_{\mathrm{P}-\mathrm{C}}=1.3 \mathrm{~Hz}, \mathrm{CH}, \mathrm{C} 6\right)$, $126.8\left(\mathrm{~d}, \mathrm{~J}_{\mathrm{P}-\mathrm{C}}=9.5 \mathrm{~Hz}, \mathrm{CH}, \mathrm{C} 10\right), 127.5(\mathrm{CH}, \mathrm{C} 12), 128.0(\mathrm{CH}$,
C1), $128.2(\mathrm{CH}, \mathrm{C} 8), 128.8(\mathrm{CH}, \mathrm{C} 7), 128.8\left(\mathrm{~d}, \mathrm{~J}_{\mathrm{P}-\mathrm{C}}=6.6 \mathrm{~Hz}\right.$, $\left.{ }_{60} \mathrm{CH}, \mathrm{C} 15\right), 128.9$ (CH, C11), 129.7 (d, J $\left.\mathrm{P}_{\mathrm{C}}=1.5 \mathrm{~Hz}, \mathrm{CH}, \mathrm{C} 16\right)$, $130.8\left(\mathrm{~d}, \mathrm{~J}_{\mathrm{P}-\mathrm{C}}=9.9 \mathrm{~Hz}, \mathrm{C}, \mathrm{C} 13\right), 131.9\left(\mathrm{~d}, \mathrm{~J}_{\mathrm{P}-\mathrm{C}}=10.3 \mathrm{~Hz}, \mathrm{CH}\right.$, C3), $134.0\left(\mathrm{~d}, \mathrm{~J}_{\mathrm{P}-\mathrm{C}}=19.5 \mathrm{~Hz}, \mathrm{CH}, \mathrm{C} 14\right), 136.5\left(\mathrm{~d}, \mathrm{~J}_{\mathrm{P}-\mathrm{C}}=15.9 \mathrm{~Hz}\right.$, C, C9), $137.0\left(\mathrm{~d}, \mathrm{~J}_{\mathrm{P}-\mathrm{C}}=3.0 \mathrm{~Hz}, \mathrm{C}, \mathrm{C} 5\right), 150.4\left(\mathrm{~d}, \mathrm{~J}_{\mathrm{P}-\mathrm{C}}=7.8 \mathrm{~Hz}, \mathrm{C}\right.$, $\mathrm{C} 2), 153.8\left(\mathrm{~d}, \mathrm{~J}_{\mathrm{P}-\mathrm{C}}=2.0 \mathrm{~Hz}, \mathrm{C}, \mathrm{C} 4\right) .{ }^{31} \mathrm{P} \mathrm{NMR}(200 \mathrm{MHz}$, ${ }_{65} \mathrm{CDCl}_{3}$ ): 11.3. HRMS (EI) for $\mathrm{C}_{22} \mathrm{H}_{17} \mathrm{P}$ : calc. (m/z) 312.1068 ; found $(\mathrm{m} / \mathrm{z}) 312.1068$.

Synthesis of 2,5-diphenylzirconacyclopentadiene 1b. A Schlenk tube was loaded with $\mathrm{Cp}_{2} \mathrm{ZrCl}_{2}(292 \mathrm{mg}, 1.0 \mathrm{mmol})$, lanthanum (93 mg, $0.66 \mathrm{mmol})$ and THF $(5 \mathrm{~mL})$. The resulting 70 mixture was stirred vigorously at room temperature until a deep red color appeared. At this stage, phenylacetylene $(0.21 \mathrm{~mL}, 2.0$ $\mathrm{mmol}$ ) was added to the reaction mixture and stirring continued for $3 \mathrm{~h}$. The solution was filtered to remove insoluble $\mathrm{LaCl}_{3}$ salts. Then the solvent was reduced to $2 \mathrm{~mL}$ under vacuum and put in 75 the fridge at $4^{\circ} \mathrm{C}$. From this solution a crop of dark red crystals of 1b suitable for $\mathrm{X}$-ray diffraction was obtained. The ${ }^{13} \mathrm{C} \mathrm{NMR}$ data is in agreement with the analogous complex $\left[\left(\mathrm{C}_{5} \mathrm{H}_{4} \mathrm{Me}\right)_{2} \mathrm{Zr}\left(\mathrm{PhC}(\mathrm{CH})_{2} \mathrm{CPh}\right)\right]{ }^{4}$

${ }^{1} \mathrm{H}$ NMR (250 MHz, $\left.\mathrm{C}_{6} \mathrm{D}_{6}\right): 5.91(\mathrm{~s}, 10 \mathrm{H}), 7.03-7.06(\mathrm{~m}, 5 \mathrm{H})$, ${ }_{80}$ 7.13-7.14 (m, 2H), 7.27-7.33 (m, 5H). ${ }^{13} \mathrm{C}$ NMR $(62.5 \mathrm{MHz}$, $\left.\mathrm{C}_{6} \mathrm{D}_{6}\right): 112.5(\mathrm{CH}), 119.6(\mathrm{CH}), 128.7(\mathrm{CH}), 129.8(\mathrm{CH}), 130.1$ (CH), $130.5(\mathrm{CH}), 130.7(\mathrm{CH}), 149.9$ (C), 192.7 (C). HRMS (ESI) for $\mathrm{C}_{26} \mathrm{H}_{23} \mathrm{Zr}[\mathrm{M}+\mathrm{H}]$ : calc. (m/z) 425.0847; found $(\mathrm{m} / \mathrm{z})$ 425.0853.

${ }_{85} \mathbf{X}$-ray crystallography. Single crystals were coated in Paratone$\mathrm{N}$ oil and mounted on a loop. Data were collected at $150.0(1) \mathrm{K}$ on a Nonius Kappa CCD diffractometer using a Mo $\mathrm{K} \alpha(\lambda=$ $0.71070 \mathrm{~A}) \mathrm{X}$-ray source and a graphite monochromator. All data were measured using phi and omega scans. The crystal structures 90 were solved using SIR 97 and refined using Shelx197.,3

DFT-analysis. Calculations were performed with the Gaussian03 and Gaussian 09 suite of programs. ${ }^{6,7}$ The B3LYP functional ${ }^{8}$ was used for computation of monomers and NBO calculations as implemented in Gaussian 03, and the B97D functional ${ }^{9}$ for 95 computation of the tetramer, as implemented in Gaussian09. The lanld $2 \mathrm{z}$ basis set and associated core potential ${ }^{10}$ were used for $\mathrm{Zr}$ atoms, and main group elements $(\mathrm{C} \text { and } \mathrm{H})^{11}$ were described with the 6-31G basis set. All basis sets were used as implemented in the program. Stationary points were identified as having no 100 imaginary frequency. NBO analyses were performed using NBO $5.9^{12}$ as implemented in Gaussian 03 .

\section{Reductive dimerization of terminal alkynes}

The reductive dimerisation of phenylacetylene using the lanthanum generated zirconocene(II), yielded a dark red solution 105 of a mixture of diphenylzirconacyclopentadienes 1a-c, as evidenced by ESI-MS, X-ray crystallography (see below) and quenching experiments (Scheme 1). Hydrolysis of this mixture 1a-c showed that the ratio of the 1,3- and 1,4-disubstituted butadiene isomers was $1: 1$, whereas the 2,3 -isomer was present in 110 lower than $5 \%$ yield according to NMR analysis. $\$$ Trace amounts of benzene derivatives were also present. ${ }^{11}$ The observed ratio for the butadienes is close to the one reported by Erker et al. obtained with a zirconocene-diene complex and phenylacetylene. However, in our case no side-products arising from the 115 zirconocene precursor were observed. This result was further 
confirmed by the reaction of 1a-c with iodine. The 1,4diiodobutadienes $\mathbf{2 a}$ and $\mathbf{2 b}$ were obtained in a 1:1 ratio according to the crude NMR spectrum. Full conversion was observed without the addition of copper catalyst. ${ }^{12}$ Compounds ${ }_{5} \mathbf{2 a}$ and $\mathbf{2 b}$ were isolated in low $25 \%$ and $18 \%$ yield, respectively, due to partial decomposition on silica gel. 2a was obtained previously only in trace amounts by the titanium-catalysed coupling of phenylacetylene. ${ }^{13}$

\section{Selective synthesis of 2,4-disubstituted phospholes}

Further transformation of diiodide 2a via iodine/lithium exchange 15 followed by addition of dichlorophenylphosphine yielded the first 2,4-diphenylsubstituted phosphole $\mathbf{3 a}$ in $65 \%$ yield (eq. 1). ${ }^{7 \mathrm{a}}$

In order to simplify the procedure and circumvent the diiodide compounds, the addition of one equivalent of $\mathrm{PhPCl}_{2}$ to 20 diphenylzirconacyclopentadienes 1a-c was investigated. Surprisingly, this did not lead to a mixture of the expected 1,2,4and 1,2,5-triphenylphospholes, but after workup 1,2,4triphenylphosphole 3a and 1,4-diphenyl-1,3-butadiene 4a were obtained in a 1:1 ratio (eq. 2, table 1). The products could be 25 separated by column chromatography and identified by multinuclear NMR spectroscopy. Further improvement was achieved when only 0.55 equivalents of dichlorophenylphosphine was added as the formation of by-products due to unreacted phosphorus reagent could be avoided. Phosphole 3a was isolated 30 as a pale-yellow, relatively air-stable solid in $70 \%$ yield based on phosphorus reagent. This methodology was then extended to a large variety of phospholes carrying aryl $\mathbf{3 b}-\mathbf{f}$, heteroaryl $\mathbf{3 g}$, alkyl $\mathbf{3 h}-\mathbf{i}$ and trimethylsilyl $\mathbf{3 j}$ groups. An initial reaction was carried out with 1.0 equivalent of $\mathrm{PhPCl}_{2}$ to determine the ratio 35 between phosphole 3 and butadiene 4 . Based on this result, in a second reaction the optimised amount of dichlorophosphine was added to prepare the phospholes 3 . The isolated yields vary between 72 and 24\% (Table 1) and in all cases, only the 2,4disubstituted phospholes were obtained. The substituents $\mathrm{R}$ on the
40 terminal alkyne have a limited influence on these ratios. The only exception is the p-chlorophenyl substituent which clearly favors the formation of 2,4-disubstituted phosphole $\mathbf{3 c} .{ }^{14}$ In order to further investigate this behaviour, the reaction with other electrophilic phosphorus reagents was examined. $\mathrm{PhPBr}_{2}$ has 45 been described as being more reactive than $\mathrm{PhPCl}_{2} \cdot{ }^{9 \mathrm{a}}$ However, when this reagent was used in the reaction with 1a-c, only compound 3a was formed. Heating at $60^{\circ} \mathrm{C}$ for $15 \mathrm{~h}$ did not influence the reaction outcome. Reaction of 1a-c with dichlorocyclohexylphosphine afforded only the 2,4${ }_{50}$ diphenylphosphole $\mathbf{3 k}$.

Table 1 Synthesis and ${ }^{31}$ P NMR data of 2,4-disubstituted phospholes

\begin{tabular}{|c|c|c|c|c|c|}
\hline Entry & $\mathrm{R}$ & $\mathrm{R}^{\prime}$ & Ratio $^{\text {a }} 3 / 4$ & Yield $^{\mathrm{b}} \mathbf{3}$ & ${ }^{31} \mathrm{P} \mathrm{NMR}^{\mathrm{c}}$ \\
\hline $\mathrm{a}$ & $\mathrm{Ph}$ & $\mathrm{Ph}$ & $1 / 1$ & $70(35)$ & 11.3 \\
\hline $\mathrm{b}$ & $\mathrm{p}-\mathrm{CH}_{3}-\left(\mathrm{C}_{6} \mathrm{H}_{5}\right)$ & $\mathrm{Ph}$ & $1 / 1$ & $61(30)$ & 10.8 \\
\hline $\mathrm{c}$ & $\mathrm{p}-\mathrm{Cl}-\left(\mathrm{C}_{6} \mathrm{H}_{5}\right)$ & $\mathrm{Ph}$ & $4 / 1$ & $46(39)$ & 12.3 \\
\hline d & p-F- $\left(\mathrm{C}_{6} \mathrm{H}_{5}\right)$ & $\mathrm{Ph}$ & $2 / 1$ & $48(34)$ & 11.9 \\
\hline $\mathrm{e}$ & $\mathrm{p}-\mathrm{OMe}-\left(\mathrm{C}_{6} \mathrm{H}_{5}\right)$ & $\mathrm{Ph}$ & $2 / 1$ & $36(26)$ & 10.6 \\
\hline $\mathrm{f}$ & 2-naphthyl & $\mathrm{Ph}$ & $2 / 1$ & $24(17)$ & 11.7 \\
\hline $\mathrm{g}$ & 2-thienyl & $\mathrm{Ph}$ & $1 / 1$ & $57(29)$ & 13.4 \\
\hline $\mathrm{h}$ & n-pentyl & $\mathrm{Ph}$ & $1 / 1$ & $63(32)$ & 8.1 \\
\hline $\mathrm{i}$ & t-butyl & $\mathrm{Ph}$ & $2 / 1$ & 47 (33) & 1.4 \\
\hline $\mathrm{j}$ & $\mathrm{Me}_{3} \mathrm{Si}$ & $\mathrm{Ph}$ & $1 / 1$ & $72(36)$ & 31.9 \\
\hline $\mathrm{k}$ & $\mathrm{Ph}$ & c- $\mathrm{C}_{6} \mathrm{H}_{11}$ & $1 / 1$ & $40(20)$ & 26.0 \\
\hline
\end{tabular}

${ }^{a}$ determined by ${ }^{1} \mathrm{H}$ NMR from the crude reaction mixture; ${ }^{\mathrm{b}}$ isolated yield under optimised conditions with respect to phosphorous reagent and in 55 parentheses with respect to zirconium reagent; ${ }^{\mathrm{c}}$ in $\mathrm{CDCl}_{3}$.

In order to ensure that the observed reactivity did not originate from the employed zirconocene source $\mathrm{Cp}_{2} \mathrm{ZrCl}_{2} / \mathrm{La}$, an experiment was conducted using phenylpropyne. As expected, in this case both phospholes $\mathbf{3 l}$ and $\mathbf{3 m}$ were formed in a 3:1 ratio in 60 an overall $66 \%$ yield (eq. 3 ).

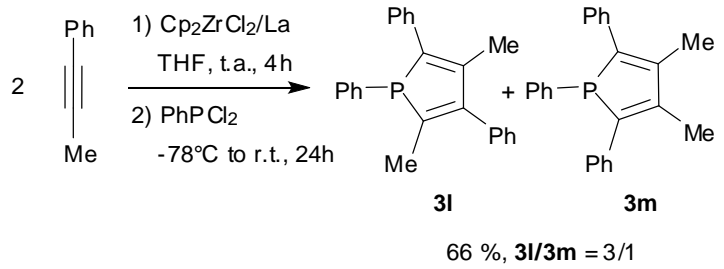

Finally, a competing experiment between di- and tetrasubstituted zirconacyclopentadienes coming from phenylacetylene 1a-c and from phenylpropyne 1d-e was 65 performed. Addition of 0.5 equivalents of $\mathrm{PhPCl}_{2}$ to this mixture 
led to the exclusive formation of phosphole 3a. Further addition of 0.5 equivalents of $\mathrm{PhPCl}_{2}$ afforded a mixture of $\mathbf{3 1}$ and $\mathbf{3 m}$, which further increased with more phosphorous reagent. The 2,5disubstituted phosphole was not observed.

5

Scheme 2 Competition experiment between di- and tetrasubstituted zirconacyclopentadienes

\section{Characterisation of 2,4-disubstituted phospholes}

\section{Multinuclear NMR spectroscopy}

${ }_{10}$ The ${ }^{31} \mathrm{P}$ NMR shifts of phospholes 3a-g are only slightly influenced by the aryl substituents going from $10.6 \mathrm{ppm}$ for the methoxy group to $13.4 \mathrm{ppm}$ for the thienyl group. Compared to the corresponding 1,2,5-triphenylphosphole $\mathbf{5 a},{ }^{15}$ compound $\mathbf{3 a}$ displays a downfield shift of $10 \mathrm{ppm}$. In the ${ }^{1} \mathrm{H}$ NMR spectra the 15 main feature of phospholes 3 is the large ${ }^{2} J_{\mathrm{P}-\mathrm{H}}$ coupling $(40 \mathrm{~Hz})$ between phosphorus and the hydrogen on the alpha ring carbon atom. In the ${ }^{13} \mathrm{C}$ NMR spectra, the ${ }^{1} J_{\mathrm{C}^{-} \mathrm{P}}$ coupling depends on the substitution, ranging from 0 to $4 \mathrm{~Hz}$ for hydrogen and aromatic substituents to $26 \mathrm{~Hz}$ for the trimethylsilyl group. Further 20 differences in the NMR shifts between differently substituted phospholes are summarized in Table 2 .

\section{X-ray analysis}

Single crystals of 3a suitable for X-ray analysis were obtained by crystallisation from diethyl ether at $4^{\circ} \mathrm{C}$ (Fig. 1). Compound 3a 25 displays many similar features compared to the 2,5-diphenyl analogue 5a (table 3). ${ }^{16,17}$ The pyramidal phosphorus atom lies 0.065(1) A below a least-square fitted phosphole plane, compared to $0.048(1) \AA$ for 5a. The P-C bonds are in the range of single bonds, with a slight difference between the unsubstituted $30(1.787(2) \AA)$ and the phenyl-substituted (1.815(2) $\AA)$ ring carbons. The double bonds in the phosphole ring (1.360(2) $\AA$ and $1.355(2) \AA)$ are localised. The phenyl rings are slightly twisted with respect to the phosphole plane $\left(\mathrm{xx}^{\circ}\right.$ and $\left.\mathrm{xx}^{\circ}\right)$ compared to $4.63(8)^{\circ}$ and $7.99(7)^{\circ}$ for $\mathbf{5 a}$.

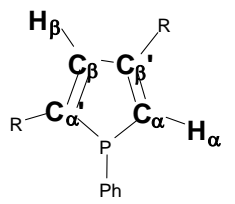

Table 2 Selected NMR data of some 2,4-disubstituted phospholes

\begin{tabular}{|c|c|c|}
\hline $\mathrm{R}$ & ${ }^{1} \mathrm{H}\left(\mathrm{H}_{\alpha}, \mathrm{H}_{\beta}\right)^{\mathrm{a}, \mathrm{b}}$ & ${ }^{13} \mathrm{C}\left(\mathrm{C}_{\alpha}, \mathrm{C}_{\alpha}, \mathrm{C}_{\beta}, \mathrm{C}_{\beta}{ }^{\prime}\right)^{\mathrm{a}, \mathrm{c}}$ \\
\hline $\begin{array}{l}\mathrm{Ph} \\
(\mathbf{3 a})\end{array}$ & 7.08 (40.0), $7.66(12.5)$ & $\begin{array}{c}128.0(0), 153.8(2.0) \\
131.9(10.3), 150.4(7.8)\end{array}$ \\
\hline $\begin{array}{c}\mathrm{p}-\mathrm{OMe}-\left(\mathrm{C}_{6} \mathrm{H}_{5}\right) \\
(\mathbf{3 e})\end{array}$ & $6.91(38.0), 7.56(12.5)$ & $\begin{array}{c}124.5(0), 153.3(1.8) \\
130.2(10.0), 150.0(7.6)\end{array}$ \\
\hline $\begin{array}{l}\text { 2-thienyl } \\
(\mathbf{3 g})\end{array}$ & 6.88 (38.5), 7.43 (11.5) & $\begin{array}{c}124.9(0), 147.0(4.4) \\
130.5(9.1), 143.8(7.8)\end{array}$ \\
\hline $\begin{array}{c}\text { t-butyl } \\
(\mathbf{3 i})\end{array}$ & $6.24(41.0), 6.75(15.0)$ & $\begin{array}{l}122.7(1.3), 161.8(7.1) \\
130.9(10.8), 165.8(9.1)\end{array}$ \\
\hline $\begin{array}{c}\mathrm{Me}_{3} \mathrm{Si} \\
(\mathbf{3 j})\end{array}$ & 7.43 (40.5), 7.29 (18.5) & $\begin{array}{c}149.4(10.8), 150.3(26.1) \\
147.4(10.1), 154.8(5.5)\end{array}$ \\
\hline \multicolumn{3}{|c|}{$\begin{array}{l}{ }^{a} \text { in } \mathrm{CDCl}_{3} ;{ }^{\mathrm{b}} \text { in parentheses }{ }^{2} J_{\mathrm{PH}} \text { and }{ }^{3} J_{\mathrm{PH}} \text { coupling constants; }{ }^{\mathrm{c}} \text { in } \\
\text { parentheses }{ }^{1} J_{\mathrm{PC}} \text { and }{ }^{2} J_{\mathrm{PC}} \text { coupling constants }\end{array}$} \\
\hline
\end{tabular}

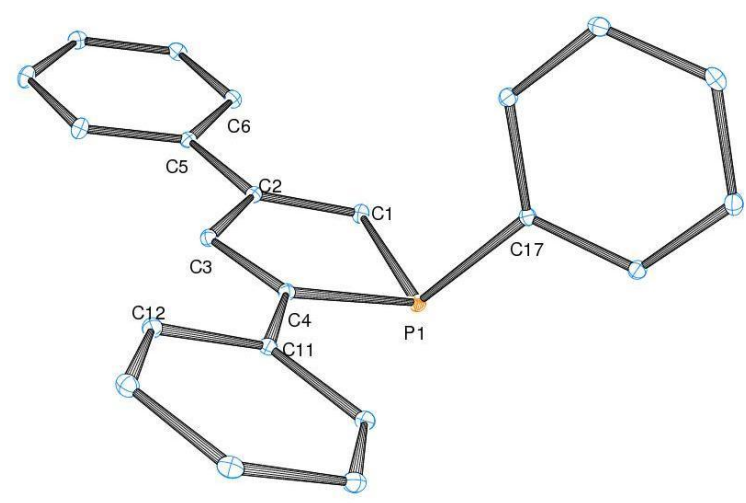

40

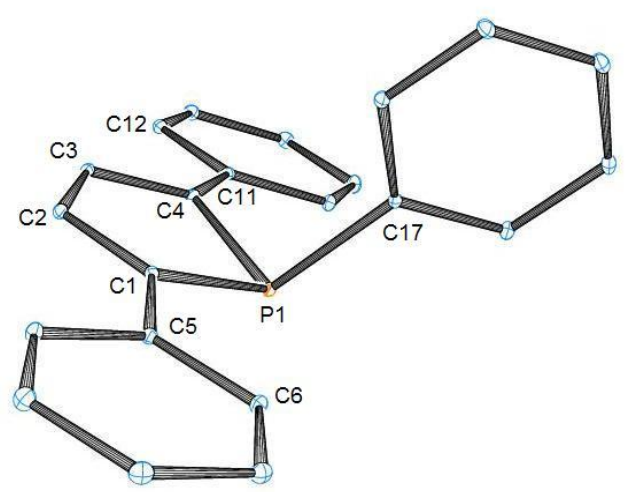

Fig. 1 Molecular structures of $\mathbf{3 a}$ and $\mathbf{5 a}$ (50\% probability ellipsoids). Hydrogen atoms are omitted for clarity.

35 
Table 3 Selected bond distances $(\AA)$ and angles $\left({ }^{\circ}\right)$ of $\mathbf{3 a}$ and $\mathbf{5 a}$

\begin{tabular}{ccc} 
& $\mathbf{3 a}$ & $\mathbf{5 a}$ \\
P1-C1 & $1.787(2)$ & $1.823(2)$ \\
P1-C4 & $1.815(2)$ & $1.824(2)$ \\
P1-C17 & $1.828(2)$ & $1.836(2)$ \\
C1-C2 & $1.360(2)$ & $1.357(2)$ \\
C2-C3 & $1.466(2)$ & $1.439(2)$ \\
C3-C4 & $1.355(2)$ & $1.359(2)$ \\
C1-P1-C4 & $90.72(7)$ & $91.34(8)$ \\
C1-P1-C17 & $105.91(7)$ & $104.33(7)$ \\
C4-P1-C17 & $104.16(6)$ & $105.49(7)$ \\
C1-C2-C3-C4 & $0.15(25)$ & $0.37(25)$ \\
& & \\
\hline
\end{tabular}

\section{Disubstituted vs. tetrasubstituted ${ }_{5}$ zirconacyclopentadienes}

It was previously observed that bulky alkyl ligands in the alpha position of zirconacyclopentadienes can hinder the formation of phospholes. ${ }^{18}$ However, the inertness of 2,5-diarylzirconacyclopentadienes towards $\mathrm{PhPCl}_{2}$ was very intriguing as 10 tetrasubstituted zirconacyclopentadienes carrying aryl groups in the 2 and 5 positions react readily with $\mathrm{PhPX}_{2}$ as previously reported and shown above. ${ }^{9 a, c}$ In order to gain more insight into this selective transformation, we focused next on the intermediate zirconacyclopentadienes.

\section{${ }_{15}$ X-ray study}

$\mathrm{X}$-ray quality crystals of $\mathbf{1 b}$ were obtained from a THF solution of a mixture of $\mathbf{1 a - c}$ at $4{ }^{\circ} \mathrm{C}$ (Fig. 2). Compound $\mathbf{1 b}$ contains two zirconacyclopentadiene complexes and one THF molecule in the unit cell. Bond lengths and angles involving zirconium are similar 20 to other zirconacyclopentadienes, as for example in $\mathrm{Cp}_{2} \mathrm{Zr}\left(\mathrm{C}_{4} \mathrm{H}_{2}(\mathrm{TTMS})_{2}\right)$ and $\mathrm{Cp}_{2} \mathrm{Zr}\left(\mathrm{C}_{4} \mathrm{Ph}_{4}\right) \cdot{ }^{9 \mathrm{a}, 14 \mathrm{~b}}$ The most important feature of $\mathbf{1 b}$ is the nearly planar phenyl-zirconacyclopentadienephenyl system with twist angles ranging from $5.33^{\circ}$ to $16.91^{\circ}$. This is in stark contrast to tetrasubstituted 25 zirconacyclopentadienes where the phenyl rings in the 2 and 5 positions are bent at $40-60^{\circ}$ due to steric crowding, for example in $\mathrm{Cp}_{2} \mathrm{Zr}\left(\mathrm{C}_{4} \mathrm{Ph}_{4}\right)$ the twist angles are $48.69^{\circ}$ and $54.34^{\circ} .{ }^{14 \mathrm{~b}, \mathrm{c}}$

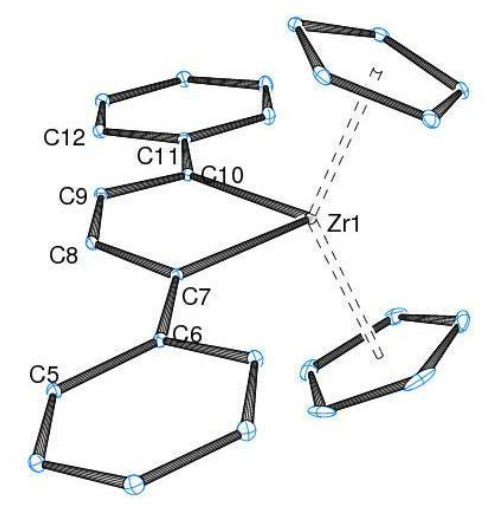

Fig. 2. Molecular structure of 2,5-diphenylzirconacyclopentadiene $\mathbf{1 b}$ 30 (50\% probability ellipsoids), only one of the two complexes is shown. A THF molecule and hydrogen atoms are omitted for clarity. Selected bond distances ( $\AA$ ) and angles $\left({ }^{\circ}\right)$ : $\operatorname{Zr}(1)-\mathrm{C}(7) 2.244(2), \operatorname{Zr}(1)-\mathrm{C}(10) 2.248(2)$, $\mathrm{Zr}(1)-\mathrm{C}(21)$ 2.465(3), $\mathrm{Zr}(1)-\mathrm{C}(24)$ 2.523(2), C(7)-C(8) 1.359(3), C(8)C(9) 1.474(3), C(9)-C(10) 1.360(3), C(7)-Zr(1)-C(10) 86.74(7)

35 When the isolated complex $\mathbf{1 b}$ was reacted with $\mathrm{PhPCl}_{2}$ in THF$\mathrm{d}^{8}$ no reaction was observed.

\section{DFT-analysis}

Based on the X-ray structure of 1b, DFT calculations using the Gaussian03 suite of programs were carried out. Initially, the 40 B3LYP functional was used, in conjunction with the 6-31G basis set for all main-group elements, and the lanl $2 \mathrm{dz}$ basis set for $\mathrm{Zr}$. It was shown that the structure of $\mathbf{1 b}$ could not be correctly calculated. A deviation in the dihedral angles of $10-20^{\circ}$ was observed. Variation of basis sets and functionals did not improve

45 the results. A closer look at the crystal structure revealed that intermolecular interactions ( $\pi$-stacking) lead to a tetrameric structure, i.e. four zirconacyclopentadienes form an independent tetramer. This structure could be correctly reproduced using the B97D functional, which takes into account dispersion effects for 50 short distance interactions (Table 4).

Table 4 Comparison of X-ray data and DFT calculations on $\mathbf{1 b}$

\begin{tabular}{cccc}
\hline Dihedral angle & X-ray data & Monomer $^{\mathrm{b}}$ & Tetramer $^{\mathrm{c}}$ \\
$\mathrm{C} 5-\mathrm{C} 8 / \mathrm{C} 35-\mathrm{C} 38\left[^{\circ}\right]$ & $16.91 / 5.33$ & 25.75 & $13.33 / 5.56$ \\
$\mathrm{C} 7-\mathrm{C} 10 / \mathrm{C} 33-\mathrm{C} 36\left[^{\circ}\right]$ & $0.86 / 0.11$ & 1.15 & $1.34 / 0.21$ \\
$\mathrm{C} 9-\mathrm{C} 12 / \mathrm{C} 31-\mathrm{C} 34\left[^{\circ}\right]$ & $12.89 / 13.3$ & 25.77 & $13.33 / 7.91$
\end{tabular}

${ }^{a}$ Two distinct complexes in unit cell; ${ }^{\mathrm{b}}$ B3LYP//6-31G $(\mathrm{H}, \mathrm{C})$ and lanl2dz $(\mathrm{Zr}) ;{ }^{\mathrm{c}} \mathrm{B} 97 \mathrm{D} / / 6-31++\mathrm{G}(\mathrm{H}), 6-31 \mathrm{G}(\mathrm{C})$ and lanl2dz $(\mathrm{Zr})$

55 In solution, it seems however more likely that the monomeric structure is prevalent. The 2,4-diphenylzirconacyclopentadiene 1a was therefore also calculated with the B3LYP functional and an NBO analysis of $\mathbf{1 a}$ and $\mathbf{1 b}$ was performed. For comparison reasons the tetrasubstituted complexes $\mathbf{1 d}$ and $\mathbf{1 e}$ arising from 60 phenylpropyne were also calculated (Table 5, Fig. 3 and 4).
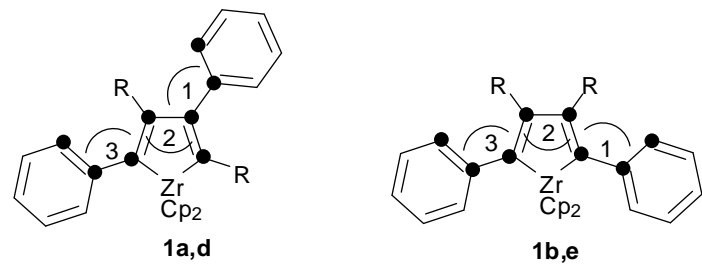

Table 5 Comparison of calculated ${ }^{\mathrm{a}}$ dihedral angles $\left(^{\circ}\right)$ of $\mathbf{1 a , b , d , e}$

\begin{tabular}{cccc}
\hline & Angle 1 & Angle 2 & Angle 3 \\
& & & \\
$2,4-\mathrm{Ph}, 3,5-\mathrm{H}(\mathbf{1 a})$ & +35.44 & +2.90 & +31.43 \\
2,5-Ph,3,4-H (1b) & +25.75 & +1.15 & +25.76 \\
$2,4-\mathrm{Ph}, 3,5-\mathrm{Me}(\mathbf{1 d})$ & +89.95 & -1.39 & -56.62 \\
$2,5-\mathrm{Ph}, 3,4-\mathrm{Me}(\mathbf{1 e})$ & +54.91 & +1.90 & +54.91 \\
& & & \\
& & \\
${ }^{\mathrm{a}} \mathrm{B} 3 \mathrm{LYP} / / 6-31 \mathrm{G}(\mathrm{H}, \mathrm{C})$ and lanl2dz (Zr) & & \\
\hline
\end{tabular}



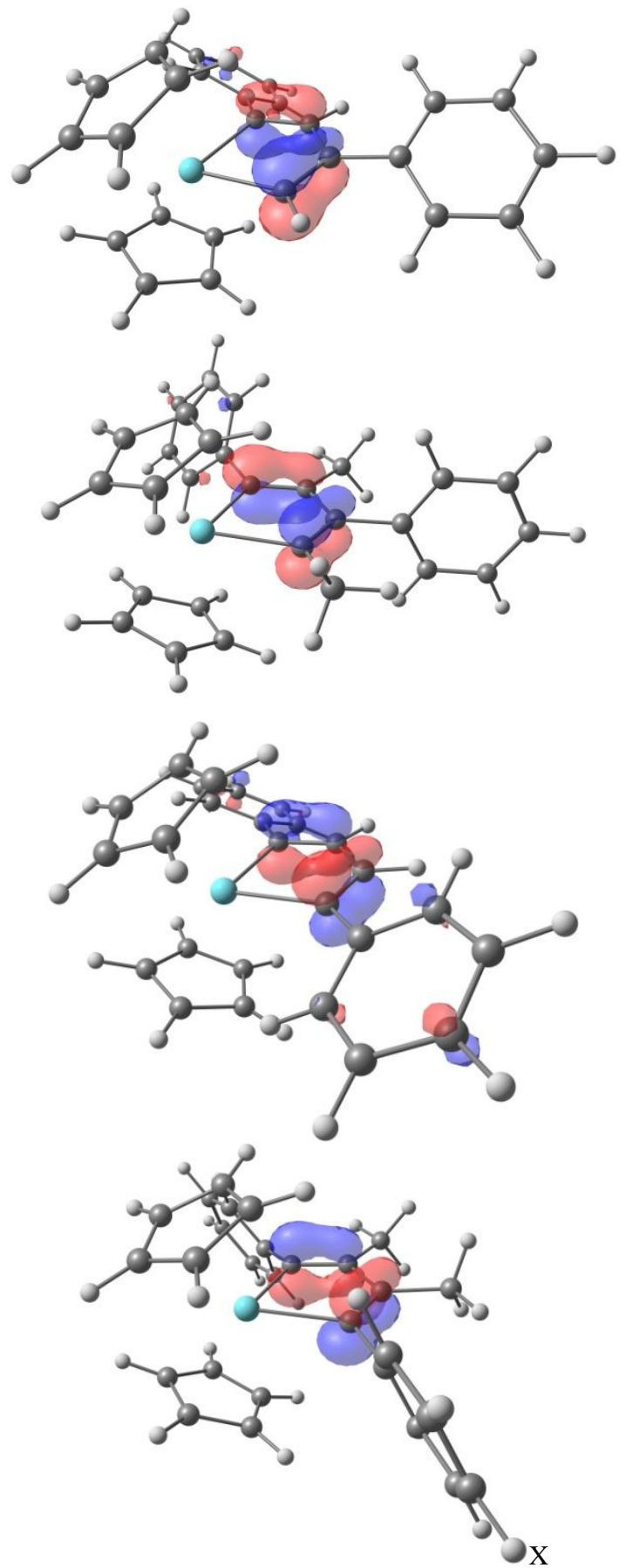

5 Fig. 3 HOMOs and optimised geometries of zirconacyclopentadienes $\mathbf{1 a}, \mathbf{1 b}, \mathbf{1 d}$ and $1 \mathrm{e}$
Fig.4 NBO analysis and HOMO energies of $\mathbf{1 a}, \mathbf{1 b}, \mathbf{1 d}$ and $1 \mathbf{e}$

10

These calculations lead to the following observations: (i) the HOMOs of all complexes are on the zirconacyclopentadiene backbones, however the energy differences are too small to explain the observed selectivity; (ii) an important difference in 15 the twist angles of the phenyl groups is observed between $\mathbf{1 b}$ $\left(25.75^{\circ}\right)$ and $1 \mathrm{e}\left(54.91^{\circ}\right)$; (iii) the unsubstituted $\alpha$-carbon in 1a has a significantly more negative charge $(-0.63)$ than the corresponding phenyl-substituted carbons in $\mathbf{1 b}(-0.41)$ and $\mathbf{1 e}(-$ 0.42 ) and the methyl-substituted carbon in 1d (-0.38). This 20 difference in charge is in agreement with a more reactive intermediate 1a compared to $\mathbf{1 b}, \mathbf{d}, \mathbf{e}$. However, the complete inertness of $\mathbf{1 b}$ towards dihalophosphines seems to be mainly related to steric hindrance arising from the small tilt angle of the phenyl groups.

\section{${ }_{25}$ Conclusions}

In conclusion a straightforward one-pot synthesis of a large series of 2,4-disubstituted phospholes has been described making use of the difference in reactivity between 2,4- and 2,5-disubstituted zirconacyclopentadienes towards electrophilic phosphorous 30 reagents. An X-ray study and DFT analyses of the intermediate zirconacyclopentadienes point towards steric reasons and only slight electronic influences to explain this selectivity. Further studies to extend this methodology to other 5-membered heteroles as well as the investigation of the chemistry of the new phosphole 35 building blocks are currently under way.

We thank the CNRS, the Universite de Reims and the Region Champagne-Ardenne for financial support and the platform PlAneT for technical support. Assistance from Miss Carine ${ }_{40}$ Machado (mass spectrometry) is acknowledged.

\section{Notes and references}

${ }^{a}$ Institut de Chimie Moléculaire de Reims, UMR CNRS 7312, Université de Reims, BP 1039, 51687 Reims, France. Fax: +33 326913166; Tel: +33 326913244; E-mail florian.jaroschik@univ-reims..fr and 45 jan.szymoniak@univ-reims.fr

${ }^{b}$ Laboratoire "Hétéroéléments et Coordination", Ecole Polytechnique and CNRS, 91128 Palaiseau Cedex, France

$\dagger$ Electronic Supplementary Information (ESI) available: Experimental and DFT data. CCDC [] See DOI: 10.1039/b000000x/ 
$\S$ The dehydrohalogenation of 1-halogenophospholium salts worked in the case of 1,3-dimethylbutadiene (ref 8a), however, 1,3-diarylbutadienes are difficult to access and readily undergo homo-Diels Alder reactions. † The ratio $\mathbf{2 a} / \mathbf{2 b}=1 / 2.5$ reported in 2006 (ref. 10) was based on GC 5 analysis and did not take into account the facile homo-Diels Alder reaction of the butadienes.

1 F. Mathey, Chem. Rev., 1988, 88, 429.

2 D. Carmichael, in Phosphorus (III) Ligands in Homogeneous Catalysis: Design and Synthesis, Chapt. 7: Phospholes, (Ed. P

$10 \quad$ Kamer and P. W. N. M. van Leeuwen), Wiley VCH, 2012.

3 (a) Y. Matano and T. Imahori, Acc. Chem. Res., 2009, 42, 1193; (b) P. Le Floch, Coord. Chem. Rev., 2006, 250, 627.

4 (a) Y. Ren and T. Baumgartner, Dalton Trans., 2012, 41, 7792; (b) Y. Matano and T. Imahori, Org. Biomol. Chem., 2009, 7, 1258; (c) T.

15 Baumgartner and R. Réau, Chem. Rev., 2006, 106, 4681.

5 S. Urig, K. Fritz-Wolf, R. Réau, C. Herold-Mende, K. Toth, E. Davioud-Charvet and K. Becker, Angew. Chem. Int. Ed., 2006, 45, 1881.

6 (a) S. Labouille, F. Nief, X.-F. Le Goff, L. Maron, D. R. Kindra, H.

20 L. Houghton, J. W. Ziller and W. J. Evans, Organometallics, 2012, 31, 5196; (b) F. Jaroschik, F.Nief, X.-F. Le Goff and L. Ricard, Organometallics, 2007, 26, 3552.

7 (a) F. Nief, B. Tayart de Borms, L. Ricard and D. Carmichael, Eur. J. Inorg. Chem., 2005, 637; (b) J. Hydrio, M. Gouygou, F. Dallemer, G.

25 G. A. Balavoine and J.-C. Daran, Eur. J. Org. Chem., 2002, 4, 675; (c) M. Ogasawara, K. Yoshida and T. Hayashi, Organometallics, 2001, 20, 1014;

8 (a) W. P. Freeman, Y. J. Ahn, T. K. Hollis, J. A. Whitaker, V.C. Vargas, R. J. Rubio, K. D. Alingog, E. B. Bauer and F. S. Tham, J. Organomet. Chem., 2008, 693, 2415; (b) G. Keglevich, T. Chuluunbaatar, A. Dobó and L. Töke, J. Chem. Soc., Perkin Trans. 1, 2000, 1495.
9 (a) O. Fadhel, Z. Benkö, M. Gras, V. Deborde, D. Joly, C. Lescop, L. Nyulászi, M. Hissler and R. Réau, Chem. Eur. J., 2010, 16, 11340;

35 (b) Y. Matano, M. Nakashima and H. Imahori, Angew. Chem. Int. Ed., 2009, 48, 4002; (c) C. Hay, M. Hissler, C. Fischmeister, J. RaultBerthelot, L. Toupet, L. Nyulászi and R. Réau, Chem. Eur. J, 2001, 7, 4222. (d) P. J. Fagan, W. A. Nugent and J. C. Calabrese, J. Am. Chem. Soc. 1994, 116, 1880.

4010 C. Denhez, S. Médégan, F. Hélion, J.-L. Namy, J.-L. Vasse and J. Szymoniak, Org. Lett., 2006, 8, 2945.

11 A. Joosten, M. Soueidan, C. Denhez, D. Harakat, F. Hélion, J.-L. Namy, J.-L. Vasse and J. Szymoniak, Organometallics, 2008, 27, 4152.

4512 C. Xi, S. Huo, T. H. Afifi, R. Hara and T. Takahashi, Tetrahedron Lett., 1997, 38, 4099.

13 S. Yamaguchi, R.-Z. Jin, K. Tamao and F. Sato, J. Org. Chem., 1998, 63, 10060.

14 (a) V. H. Gessner, J. F. Tannaci, A. D. Miller and T. Don Tilley, Acc. 50 Chem. Res., 2011, 44, 435. (b) A. D. Miller, J. F. Tannaci, S. A Johnson, H. Lee, J. L. McBee and T. Don Tilley, J. Am. Chem. Soc., 2009, 131, 4917. (c) S. A. Johnson, F.-Q. Liu, M. C. Suh, S. Zürcher, M. Haufe, S. S. H. Mao and T. Don Tilley, J. Am. Chem. Soc., 2003, 125, 4199.

5515 B. Lukas, R. M. G. Roberts, J. Silver and A. S. Wells, J. Organomet. Chem., 1983, 256, 103.

16 W. P. Ozbirn, R. A. Jacobsen and J. C. Clardy, J. Chem. Soc. D, 1971, 1062 .

17 A low-temperature $(150 \mathrm{~K})$ crystal structure of $5 \mathbf{a}$ was recorded.

6018 F. Nief, D. Turcitu and L. Ricard, Chem. Commun., 2002, 1646. 